DOI: https://doi.org/10.32838/2523-4803/70-4-11

УДК 338.24.01

\title{
Павлова Р.К.
}

кандидат економічних наук, доцент кафедри менеджменту

та міжнародних економічних відносин,

Таврійський національний університет імені В.І. Вернадського

Іваненко В.В.

кандидат економічних наук, доцент кафедри менеджменту

та міжнародних економічних відносин,

Таврійський національний університет імені В.І. Вернадського

\section{Pavlova Rimma, Ivanenko Valentyna}

Taurida National V.I. Vernadsky University

\section{МОДЕЛЮВАННЯ СТРУКТУРИ СИСТЕМИ УПРАВЛІННЯ ОРГАНІЗАЦІЕЮ}

\begin{abstract}
Управління організацією в умовах динамічного ринкового середовища потребує постійної уваги як науковців, так і практиків. Структура системи управління під впливом зовнішніх та внутрішніх змін потребує корегування. Актуальним залишається питання формування ефективних структур управління на основі системного підходу. У статті розглянуто сутність організації як об 'єкта управління, визначено, щзо під ичи поняттям розуміють не лише підприємства, фірми, а й макроструктури, а саме регіон, державу, окремі галузі. Зроблено акиент на розумінні сутності структури. В основу дослідження та обтрунтувань покладено системний підхід до управління. Проаналізовано та оцінено підходи до моделювання структури системи управління організачією на рівні виробничих підприємств. На основі існуючих методів запропоновано методику розроблення моделей структури системи управління на рівні економіки краӥни, окремих галузей, регіонів, щуо є авторськими обгрунтованими пропозиціями, які можна використовувати у практичній діяльності державними інституційними структурами.

Ключові слова: організація, структура управління, моделювання, система, макрорівень, методика, методи.
\end{abstract}

Постановка проблеми. Теорія управління організацією розвивається у часі поряд зі змінами в умовах функціонування господарюючих структур та з розвитком менеджменту як науки. Побудова раціональних структур управління потребує особливої уваги як у науковому, так і практичному аспекті, особливо з позиції системності управлінського процесу та підходу до структури організації як системи.

Дослідження еволюції моделей структур управління організацією дає можливість зауважити, що кожна 3 типових структур управління організацією буде ефективною за певних умов господарювання, тобто залежить від організаційно-правових форм господарюючих суб'єктів, від їхніх цілей, завдань тощо. Постає також питання відносно визначення найбільш ефективної структури системи управління в конкретних умовах, що, на нашу думку, можливо вирішити за допомогою розроблених авторами та запропонованих підходів до моделювання структури системи управління.

Аналіз останніх досліджень і публікацій. Для якісного дослідження проблеми було проведено аналіз підходів до моделювання та моделей структур управління організацією, у яких застосовується системний підхід та визначаються: сукупність підсистем та елементів управлінської структури; рівень ієрархії підсистем та елементів; сукупність визначених характеристик цих підсистем; сукупність функцій кожного складника підсистеми; інформаційна складник, що покладений в основу моделювання, тощо. Саме цим питанням присвячено праці провідних вітчизняних та зарубіжних учених, а саме: М.Х. Мескона [6], М. Альберта [6], Ф. Хедоурі [6], В.Б. Уткіна [9], В.І. Старикова [7], Г.А. Титаренка [8], В.М. Глушкова [1], М.М. Клименюка [2], О.С. Кузьміна [3], А.В. Катренка [4], В.Р. Кігеля [5] та ін. Проте у науковій літературі є досить велика кількість протиріч, дискусій щодо моделювання структури системи управління, яка може бути ефективною для організацій різного рівня. Відповідно, дана проблематика потребує подальшого розвитку.

Формулювання цілей статті. Дослідження наукових праць та практичних проблем управління організацією показало, що низка питань теоретичного та методичного характеру щодо побудови ефективних структур управління залишається недостатньо розробленою. Метою даної статті є обгрунтування нових підходів до моделювання структур управління організаціями макрорівня на основі системного підходу. 
Виклад основного матеріалу. У вітчизняній та зарубіжній теорії та практиці визначено основні типи структур управління організацією переважно на рівні підприємства, які забезпечують його функціонування як цілісної системи та орієнтовані на реалізацію визначеної місії, цілей та завдань суб'єкта господарювання. Проте у сучасних динамічних, змінних умовах розвитку бізнесу на конкурентній основі важливим $є$ корегування існуючих структур, створення тимчасових структур, які орієнтовані на реалізацію конкретних проектів, що має функціональний аспект. Постає також питання щодо визначення їх місця в існуючій структурі управління та взаємовідносин із ієрархічною структурою, що реалізує процес управління організацією як цілісною системою. У результаті диверсифікації діяльності, товарної чи ринкової, може також поставати питання щодо внесення змін до структур управління, але основною умовою повинно бути збереження системності, комплексності, цілісності у функціонуванні організації. Сьогодні розроблено значну кількість моделей структур систем управління на рівні підприємства, але у науковій літературі недостатньо уваги приділяється питанням визначення структури системи управління організаціями макрорівня.

Слід зазначити, що, на думку М.Х. Мескона, М. Альберта, Ф. Хедоурі, організацію розглядають як групу людей, діяльність яких свідомо координується для досягнення загальної цілі або цілей [6, с. 31]. Під організацією також можна розуміти підприємство, галузь, народне господарство, державу, наддержавні устрої.

Із погляду теорії систем організацію можна розглядати як деяку систему, що має своє внутрішнє та зовнішнє середовище і потребує управління. Як було зазначено вище, зміни як у самій системі, так і у зовнішньому середовищі потребують постійної реакції на них, тобто вирішення конкретних завдань управління.

Як відомо, необхідною умовою існування будь-якої системи $є$ наявність управління, що орієнтоване на створення та здійснення цілеспрямованих керуючих дій по відношенню до системи у цілому. Відповідно, системи в яких протікають процеси управління, мають назву систем управління.

Як зазначає М.М. Клименюк, «система управління визначається як така, що має дві тісно пов'язані між собою основні складові частини, які утворюються 3 елементів системи і мають назву підсистем: орган управління та об'єкт управління» [2, с. 34-72] (керуюча та керована системи).

За баченням В.М. Глушкова, об'єкт управління, використовуючи різні види ресурсів та відповідні технологічні процеси, перетворює їх на готові продукти (продукцію чи послуги), що є результатом діяльності організації. В об’єкті управління здійснюються матеріальні перетворення предмету праці у готовий продукт [1]. Орган управління можна розглядати як підсистему, яка на основі вхідної інформації та виходячи 3 мети системи має розробляти управлінські рішення та передавати їх об'єкту управління для виконання, тобто здійснювати збір, переробку та передачу необхідної інформації до об'єкта управління.

Отже, від достовірності, своєчасності та якості отриманої, обробленої та переданої користувачу інформації залежить ефективність функціонування всієї системи управління. А це означає, що будь-яка діюча система управління потребує у своєму складі науково обгрунтовані та практично необхідні: по-перше, окремі складники - елементи системи; по-друге, достатню кількість цих елементів; по-третє, ефективні зв'язки між ними.

Процес моделювання, на нашу думку, має пряме відношення до конкретних структур. Відповідно, структуру можна розглядати як сукупність стійких зв'язків об'єкта, що забезпечують його цілісність, тотожність самому собі, тобто збереження основних властивостей за різних зовнішніх та внутрішні змін. Будь-яке підприємство має структуру, яка поєднує всі служби, підрозділи, органи. Саме тому структура управління є одним 3 основних понять менеджменту, бо саме в межах структури проходить управлінський процес, починаючи зі збирання та оброблення інформації і закінчуючи процесами контролю та регулювання.

Теоретичні дослідження дають різні підходи до визначення та побудови структури системи управління. Усі вони визнають, що у межах побудованої структури проходить весь управлінський процес організації, у якому беруть участь керівники всіх рівнів, усіх напрямів діяльності.

На нашу думку, один із найбільш теоретично обгрунтованих підходів, який можна покласти в основу моделювання структури системи управління організацією на рівні підприємства та має широке практичне застосування, розроблено професором М.М. Клименюком, де автор обгрунтовує той факт, що «структура системи управління визначається як множина усіх завдань управління, які потрібно розв'язати у конкретній системі управління» [2, с. 54-75]. Підхід грунтується на визначенні окремого завдання управління як елементу структури системи управління та виявленні повної множини завдань управління об'єктом. Це, по-перше, є необхідною умовою для якісного управління організацією, а по-друге, $є$ основою побудови організаційної структури органу управління через поєднання завдань у відповідні комплекси.

Методика, запропонована М.М. Клименюком, полягає у декомпозиції, іншими словами, поділі системи управління (всієї інформації, що відноситься до управління організацією) на частини за вибраними ознаками [2, с. 54]. Автором обгрунтовано, що такими ознаками для діючого підприємства є:

- вид керованого процесу, оскільки діяльність організації спрямована на процеси виробництва та забезпечення виробництва продукту;

- номер виробничого підрозділу об'єкта управління, оскільки потрібно виявити, де конкретно виробляється продукт або його складники;

- фаза управління, бо для здійснення процесу управління потрібно реалізувати комплекс фаз, а саме планування, облік, контроль та регулювання; 
- період управління, оскільки управлінський процес здійснюється у визначені часові проміжки [2, с. 65].

На основі запропонованого поділу системи управління підприємством можна отримати множину всіх завдань управління, тобто елементів системи управління, та показати зв'язки між ними, визначити їх стійкість.

Маючи інформацію про складність розв'язання одного завдання управління, легко визначити потрібну кількість управлінського апарату як у цілому по всій організації, так і по кожному структурному підрозділу. При цьому можна забезпечити раціональний поділ праці та виключити дублювання функцій в управлінському апараті.

На основі глибокого аналізу різних підходів, окремих методів та методик щодо моделювання структури системи управління, які представлено у наукових працях О.С. Кузьміна [3], Л.В. Катренка [4], В.Р. Кігеля [5], В.І. Старикова [7], Г.А., Титаренка [8], В.Б. Уткіна [9], ми спробували розробити власну методику моделювання структури системи управління такими складними системами, як економіка країни, регіону чи окремих галузей. Проте за основу запропонованого авторами моделювання структури системи управління взято підходи, що запропоновані М.М. Клименюком [2], по відношенню до виробничого підприємства.

Відповідно до описаної методики, потрібно так здійснити декомпозицію системи управління економікою країни, щоб було забезпечено поділ праці, за якого стане неможливим дублювання функцій апарату управління відповідної керованої системи.

Під час вибору ознак декомпозиції будемо дотримуватися найважливішої вимоги, що поділ системи або підсистем на кожному рівні має здійснюватися лише за однією ознакою.

Слід зазначити, що систему управління можна визначити також як множину завдань управління, які потрібно розв'язати для того, щоб досягти поставлених перед організацією цілей. Отже, мета декомпозиції полягає в отриманні повного переліку завдань управління організацією, при цьому складність кожного завдання має бути такою, щоб ії порівняно легко можна було розв'язати.

Розглянемо застосування моделі до економічного сектору держави, спрямованого на процеси виробництва. Як відомо, виробництво - це економічна діяльність, результатом якої є продукт (продукція, послуга). Будь-яке виробництво реалізується через виробничі процеси, що здійснюється у відповідних галузях народного господарства. Сукупність усіх виробничих одиниць, що здійснюють переважно однакові чи подібні види економічної діяльності, можна називати галуззю. Належність до галузі визначається на підставі класифікатора видів економічної діяльності (КВЕД), що є складовою частиною державної системи класифікації і кодування техніко-економічної та соціальної інформації в Україні.

Отже, за аналогією з описаною методикою можна також вибирати ознаки декомпозиції системи управління на рівні економіки країни.
За першу ознаку вибираємо вид керованого процесу - виробничу діяльність галузей, видів економічної діяльності. Позначимо систему управління економічним сектором держави через літеру $\mathrm{S}$, а підсистеми (блоки), на які вона буде поділена, - через множину $\left(S_{1}, S_{2}, \ldots, S_{k}, \ldots, S_{K}\right)$, де $\mathrm{k}-$ вид керованого процесу (галузь) (перша ознака), а $\mathrm{K}$ - кількість таких керованих процесів, $\mathrm{k}=\overline{1, \mathrm{~K}}$. Отже поділ системи на частини за першою ознакою можна записати системами формул (1):

$$
\bigcup_{\mathrm{k}=1}^{\mathrm{K}} \mathrm{S}_{\mathrm{k}}=\mathrm{S} ; \mathrm{ra} \bigcap_{\mathrm{k}=1}^{\mathrm{K}} \mathrm{S}_{\mathrm{k}}=\varnothing .
$$

Системи формул (1) означають той факт, що поєднання всіх підсистем $S_{k}$ дають повну систему $\mathrm{S}$, а перетин цих підсистем дають пусту (порожню) множину. Таким чином, кількість підсистем, отриманих у результаті декомпозиції системи на частини за першою ознакою, становить К підсистем.

Кожна 3 підсистем (блоків) $\mathrm{S}_{\mathrm{k}}$ містить окрему секцію виду економічної діяльності. Вона $є$ простішою за всю систему S, проте $\epsilon$ досить складною для розв'язання всіх проблем, які стоять перед цією підсистемою. Отже, потрібно продовжувати декомпозицію системи та вибрати другу ознаку поділу кожну з підсистем $\mathrm{S}_{\mathrm{k}}$. За другу ознаку декомпозиції у методиці запропоновано вибрати виробничий підрозділ, в якому виконуються виробничі процеси. У нашому разі це окремі виробничі одиниці, а саме відповідні підприємства, організації, які розташовані по всій території країни. Адміністративно територія держави поділяється на регіони (області, міста, селища) державного підпорядкування.

Відповідно, за наступну ознаку доцільно вибрати номер виробничої одиниці у розрізі регіонів країни. Кожну з підсистем (блоків) $S_{k}$, отриманих у результаті поділу системи $\mathrm{S}$ за першою ознакою, потрібно поділити за наступною, другою ознакою на $\mathrm{L}$ частин $\left(S_{11}, S_{12}, \ldots, S_{k l}, \ldots S_{K L}\right)$, де $l$ - номер виробничої одиниці, по відношенню до якої виконується певний керований процес, L - кількість таких виробничих одиниць, $l=\overline{1, \mathrm{~L}}$. Тоді поділ системи на частини за другою ознакою можна записати системами формул (2) :

$$
\bigcup_{l=1}^{L} S_{k l}=S_{k} ; \mathrm{ra} \bigcap_{l=1}^{L} S_{k l}=\varnothing ; k=\overline{1, K} .
$$

Системи формул (2) означають той факт, що поєднання всіх підсистем $S_{k l}$, отриманих за другою ознакою, дають відповідну підсистему $S_{k}$, а перетин цих підсистем дає пусту (порожню) множину.

Отже, кількість підсистем, отриманих у результаті декомпозиції системи на частини за двома ознаками (за першою та другою), становить $\mathrm{K} * \mathrm{~L}$ підсистем. Кожна 3 підсистем (блоків) $\mathrm{S}_{\mathrm{kl}}$ передбачає належність певного виду економічної діяльності до відповідної виробничої одиниці регіону. Вона $є$ більш простою по відношенню до підсистеми $\mathrm{S}_{\mathrm{k}}$, проте $\epsilon$ досить складною для розв'язання всіх проблем, які стоять перед відповідною підсистемою. Потрібно продовжувати декомпозицію системи та вибрати третю ознаку поділу кожної 3 підсистем $S_{k l}$. 
За третю та четверту ознаки декомпозиції системи управління доцільно вибрати запропоновані в методиці проф. М.М. Клименю каповний комплекс фаз (функцій) управління (третя ознака) та період управління відповідно (четверта ознака) [3, с. 62-64].

Отже, кожну із підсистем, отриманих за двома ознаками поділу системи на частини $S_{k l}$, потрібно поділити за третьою ознакою декомпозиції - фазою управління. У цьому разі загальну кількість фаз управління, що потрібно здійснити в кожній підсистемі $S_{k l}$, позначимо літерою Р, отже, $\mathrm{p}=\overline{1, \mathrm{P}}$, де $\mathrm{p}-$ номер фази управління. Підсистеми поділу системи на частини за трьома ознаками пропонується записати так: $S_{111}, S_{112}, \ldots, S_{k l p}, \ldots, S_{K L P}$. Тоді поділ системи на частини за третьою ознакою у загальному вигляді можна представити системами формул (3):

$$
\bigcup_{p=1}^{P} S_{k l p}=S_{k l} ; \text { та } \bigcap_{p=1}^{P} S_{k l p}=\varnothing ; k=\overline{1, K}, l=\overline{1, L} .
$$

Системи формул (3) означають той факт, що поєднання всіх підсистем $S_{k l p}$, отриманих за третьою ознакою, дають відповідну підсистему $S_{k l}$, що отримана в результаті декомпозиції за двома ознаками, а перетин цих підсистем дає пусту (порожню) множину. Кількість підсистем, отриманих у результаті декомпозиції системи на частини за трьома ознаками за першою, другою та третьою, становить у загальному вигляді $\mathrm{K} * \mathrm{~L} * \mathrm{P}$ підсистем.

Кожна 3 підсистем (блоків) $\mathrm{S}_{\mathrm{k} l p}$ визначає певну фазу управління окремим керованим процесом (видом економічної діяльності) у відповідній виробничій одиниці регіонів. Вона є простішою за відповідну підсистему $\mathrm{S}_{\mathrm{kl}}$, проте досить складною для розв'язання всіх проблем, які стоять перед цією підсистемою, хоча б тому, що вирішувати питання підсистеми $\mathrm{S}_{\mathrm{k} / p}$ потрібно з урахуванням терміну управлінського процесу.

Четверта ознака декомпозиції - це період управління, а саме термін часу, протягом якого потрібно приймати рішення. Структура періоду може бути різною. Найчастіше організації застосовують таку структуру періоду, в яку входять такі інтервали часу: рік, квартал, місяць, тиждень, доба. Таким чином, кожну з підсистем, отриманих за трьома ознаками поділу системи на частини $S_{k l p}$, потрібно поділити за четвертою ознакою декомпозиції - період управління. У цьому разі загальну кількість періодів управління, за які потрібно прийняти управлінське рішення в кожній підсистемі $S_{k l p}$, позначимо літерою $\mathrm{T}$, а саме $\mathrm{t}=\overline{1, \mathrm{~T}}$. Підсистеми поділу системи на частини за чотирма ознаками доцільно записати так: $S_{1111}, S_{1112}, \ldots, S_{k l p t}, \ldots, S_{K L P T}$. Тоді поділ системи на частини за четвертою ознакою у загальному вигляді можна записати системами формул (4):

$$
\bigcup_{t=1}^{T} S_{k l p t}=S_{k l p} ; \text { та } \bigcap_{t=1}^{T} S_{k l p t}=\varnothing ; k=\overline{1, K}, l=\overline{1, L}, p=\overline{1, P} .
$$

Системи формул (4) означають той факт, що поєднання всіх підсистем $S_{k l p t}$, отриманих за четвертою ознакою, дають відповідну підсистему $S_{k l p}$, що отримана в результаті декомпозиції за трьома ознаками, а перетин цих підсистем дає пусту (порожню) множину.
Отже, кількість підсистем, отриманих у результаті декомпозиції системи на частини за першою, другою, третьою та четвертою ознаками, становить у загальному вигляді $\mathrm{K} * \mathrm{~L} * \mathrm{P} * \mathrm{~T}$ підсистем.

Відповідно, кожна з підсистем (блоків) $\mathrm{S}_{\mathrm{k} l p t}$ визначає певну фазу управління окремого виду економічної діяльності у відповідній виробничій одиниці регіонів на певний проміжок (або в певному проміжку) часу. Для обробки інформації в кожній такій підсистемі можна широко застосовувати розроблені в теорії економікоматематичні моделі розв'язання конкретних задач.

Отримана у результаті застосування методу декомпозиції кожна підсистема $S_{k l p t}$ має тільки по одному параметру кожної з чотирьох описаних властивостей. Тобто кожна $S_{k l p t}$ містить комплекс інформації тільки про один процес управління, про один виробничий підрозділ, про одну фазу управління, про один період управління, яка не повторюються в інших підсистемах. Інакше кажучи, кожну із цих підсистем можна представити як задачу управління. Відповідно, множину всіх взаємопов'язаних задач управління можна вважати системою управління. Кількість усіх задач у системі управління у числовому виразі дорівнює величині $\mathrm{K} * \mathrm{~L} * \mathrm{P} * \mathrm{~T}$.

Таким чином, структуру системи управління можна описати множиною таких підсистем (задач) (формула 5):

$$
S_{k l p t}=\{k=\overline{1, K} ; l=\overline{1, L} ; p=\overline{1, P} ; t=\overline{1, T}\} .
$$

Під час практичного використання методики побудови структури системи управління будь-якою організацією слід ураховувати той факт, що кожна ознака декомпозиції має свою ієрархічну структуру.

Розглянутий підхід дає можливість отримати теоретично обгрунтовану структуру системи управління економікою країни 3 повним переліком задач управління. Проте на практиці застосовувати таку методику буде досить непросто, адже не всі види економічної діяльності представлені у всіх регіонах держави, тому на практиці, як правило, виникає необхідність у визначенні структури системи управління в окремих, а не разом у всіх галузях народного господарства. Керівництво регіонів повинно бути зацікавлене у визначенні чіткої структури системи управління саме свого регіону.

У таких випадках систему управління країною було б доцільно будувати в одному з двох напрямів. Перший напрям - галузевий, полягає у тому, щоб розглядати економіку держави як поєднання галузей народного господарства, до складу яких входять підприємства відповідних галузей. Другий напрям - адміністративний, який полягає у тому, щоб розглядати економіку держави як поєднання регіонів (областей), до складу яких входять підприємства (організації) відповідних регіонів із зазначенням їх галузевої належності.

Розглянемо перший напрям. Як було зазначено, належність до галузі визначається відповідно до Класифікатора видів економічної діяльності (КВЕД), що являє собою ієрархічну структуру. У цій структурі перший рівень - це секції (види економічної діяльності в укрупненій номенклатурі), їx 21, які позначаються літе- 


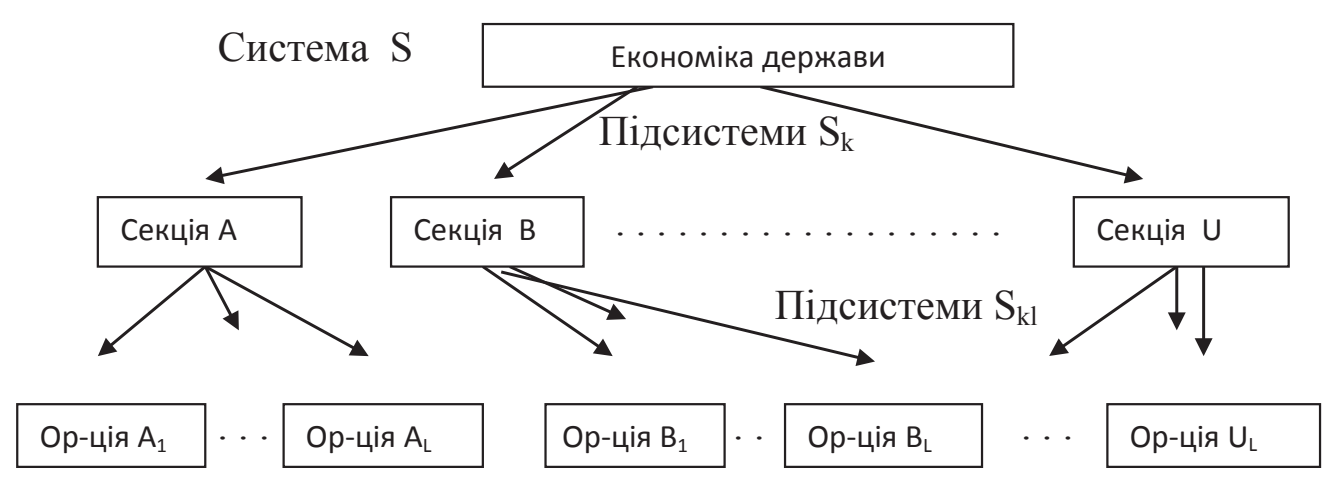

Рис. 1. Фрагмент галузевої структури економіки держави

Джерело: складено авторами

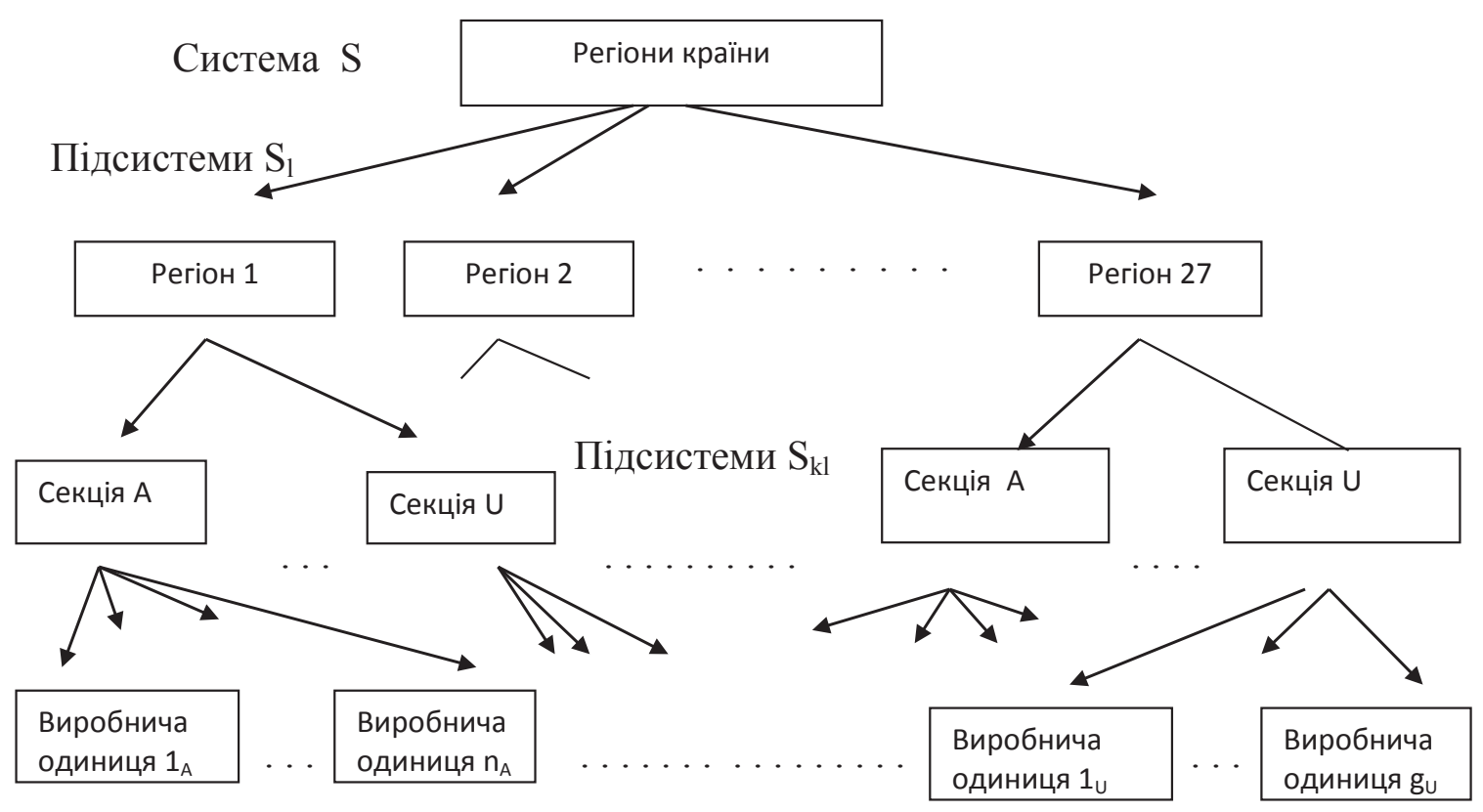

Рис. 2. Фрагмент адміністративно-територіальної структури економіки держави

Джерело: складено авторами

рами латинської абетки від А до U. Наступні рівні - це деталізація, поділ видів економічної діяльності на розділи (їх загальна кількість - 88). Кожний розділ поділяється на групи, їх загальна кількість - 272. Кожна група поділяється на класи, їх загальна кількість -615 . Як бачимо, структура КВЕД є досить інформаційно об’ємною. Якщо до структури КВЕД додати перелік тих підприємств, що належать до відповідних видів економічної діяльності у країні, то отримаємо структуру економіки держави у розрізі галузей народного господарства. Тобто отримаємо перелік підсистем, що описані формулою 2. На рис. 1 представлено фрагмент галузевої структури економіки держави.

Якщо продовжити поділ підсистем $S_{k l}$ за ознаками фаз управління та періодом управління, отримаємо повний перелік задач управління економікою держави за галузевим напрямом.

Система управління окремою галуззю (нехай це буде галузь за номером і) буде такою:

$$
S_{k}=k=i ; l=\overline{1, L_{\text {держ. }}} ; p=\overline{1, P} ; t=\overline{1, T},
$$

де $i$ - номер галузі, що розглядається; $i=\overline{1, I}$;

$I$ - кількість галузей по яких потрібно побудувати структуру системи управління;

$L_{\text {держ. }}$ - кількість виробничих одиниць держави, що працюють у певній галузі.

Другий напрям - адміністративний. Адміністративно територія держави поділяється на регіони державного підпорядкування. В Україні таких регіонів 27 (з урахуванням тимчасово окупованих територій).

На рис. 2 представлено фрагмент адміністративнотериторіальної структури економіки держави.

Кожен із регіонів країни має чіткий список своїх виробничих одиниць, а також список галузей діяльності відповідно до КВЕД, виробнича діяльність яких здійснюється в регіоні. Таким чином, знаючи ієрархічну структуру першої та другої ознак декомпозиції системи управління, кожний регіон може отримати 
повний перелік задач управління відповідною організацією та зв' язками між ними (третя та четверта ознаки декомпозиції є незмінними).

Система управління окремим регіоном (нехай це буде регіон за номером ј) буде такою:

$$
S_{l}=\left\{k=\overline{1, K_{j}} ; l=j ; p=\overline{1, P} ; t=\overline{1, T}\right\},
$$

де $j$ - номер регіону, що розглядається; $j=\overline{1, J}$;

$J$ - кількість регіонів держави, по яких потрібно побудувати структуру системи управління;

$K_{j}-$ кількість галузей народного господарства, до яких належать виробничі одиниці $j$-го регіону.

Отже, запропонована методика може бути використана під час побудови структур управління макрорівня, а саме на рівні держави, регіону, а також окремих галузей. Такий підхід також дає можливість більш раціо- нально визначати кількість управлінського персоналу організацій державного чи регіонального рівня, його конкретні завдання, що виключить дублювання функціональних обов'язків. Проте основною проблемою під час побудови структури системи управління організацією макрорівня є підготовка вхідної інформації.

Висновки. Таким чином, у зарубіжній, вітчизняній науці та практиці існує значна кількість методів моделювання управлінського процесу різними організаціями на різних рівнях. Проте запропонована методика побудови структури системи управління, що грунтується на методі декомпозиції, який отримав широке застосування в організаціях мікрорівня, може бути успішно використана для побудови моделі структури системи управління організаціями макрорівня.

\section{Список літератури:}

1. Глушков В.М. Введение в АСУ. Киев : Техніка, 1974. 320 с.

2. Клименюк М.М. Менеджмент : експрес-підручник / заг. ред. М.М. Клименюка. Київ : Міленіум, 2017.174 с.

3. Кузьмін О.Е., Георгіаді Н.Г. Формування і використання інформаційної системи управління економічним розвитком підприємства : монографія. Львів : Львівська політехніка, 2006. 368 с.

4. Катренко А.В., Пасічнік В.В., Пасько В.П. Теорія прийняття рішень : підручник / за заг. ред. М.3. Згуровського. Київ : ВНV, 2009. 448 с.

5. Кігель В.Р. Методи і моделі підтримки прийняття рішень у ринковій економіці : монографія. Київ : ЦУЛ, 2003.2002 с.

6. Мэскон М.Х., Альберт М., Хедуори Ф. Основы менеджмента / пер. с англ. Москва : Дело, 1998. 704 с.

7. Стариков В.И. Информационные системы : учебное пособие. Омск : ОмГТУ, 2006. 64 с.

8. Титаренко Г.А. Информационные технологии управления : учебное пособие. Москва : ЮНИТИ-ДАНА, 2007. 439 с.

9. Уткин В.Б. Информационные системы и технологии в экономике : ученик. Москва : ЮНИТИ-ДАНА, 2008. 335 с.

\section{References:}

1. Glushkov V.M. (1974) Vvedeniye v ASU [Introduction to ACS]. Kyiv: Technique, p. 320. (in Ukrainian)

2. Klimenyuk M.M. (2017) Menedzhment: yekspres-pidruchnik [Management: express textbook]. Kyiv: Millennium, p. 174. (in Ukrainian)

3. Kuzmin O.E., Kuzmin O.E., Georgiadi N.G. (2006) Formuvannya i vikoristannya informatsiynoï sistemi upravlinnya yekonomichnim rozvitkom pidpriemstva [Formation and use of information system of management of economic development of the enterprise]. Lviv: Lviv Polytechnic. (in Ukrainian)

4. Katrenko A.V., Beekeeper V.V., Pasko V.P. (2009) Teoriya priynyattya rishen': pidruchnik [Theory of decision making: a textbook]. Kyiv: BHV, p. 368. (in Ukrainian)

5. Kigel V.R. (2003) Metodi i modeli pidtrimki priynyattya rishen'u rinkoviy yekonomitsi [Methods and models of decision support in a market economy: a monograph]. Kyiv: TSUL, p. 2002. (in Ukrainian)

6. Mascon M.H., Albert M., Hallowory F. (1998) Osnovy menedzhmenta [Fundamentals of Management]. Moscow: Delo, p. 704. (in Russian)

7. Starikov V.I. (2006) Informatsionn·yye sistemy [Information systems]. Omsk: Omsk State Technical University, p. 64. (in Russian)

8. Titarenko G.A. (2007) Informatsionn yye tekhnologii upravleniya [Information Technology Management]. Moscow: UNITY - DANA, p. 439. (in Russian)

9. Utkin V.B. (2008) Informatsionn yye sistemy i tekhnologii v ekonomike [Information systems and technologies in the economy]. Moscow: UNITY - DANA, p. 335. (in Russian) 


\section{МОДЕЛИРОВАНИЕ СТРУКТУРЫ СИСТЕМЫ УПРАВЛЕНИЯ ОРГАНИЗАЦИЕЙ}

Управление организацией в условиях динамичной рыночной среды требует постоянного внимания как ученых, так и практиков. Структура системы управления под влиянием внешних и внутренних изменений нуждается в корректировке. Актуальным остается вопрос формирования эффективных структур управления на основе системного подхода. В статье рассмотрена сущность организации как объекта управления, определено, что под этим понятием понимают не только предприятия, фирмы, но и макроструктуры, а именно регион, государство, отдельные отрасли. Сделан акиент на понимании сущности структуры. В основу исследования и обоснований положен системный подход к управлению. Проанализированы и оценены подходы к моделированию структуры системы управления организащией на уровне производственных предприятий. На основе существующчих методов предложена методика разработки моделей структуры системы управления на уровне экономики страны, отдельных отраслей, регионов, являющейся авторскими обоснованными предложениями, которые можно использовать в практической деятельности государственными институциональными структурами.

Ключевые слова: организация, структура управления, моделирование, система, макроуровень, методика, методbl.

\section{MODELING OF CONTROL STRUCTURES OF ORGANIZATION}

Managing an organization in a rapidly changing market environment requires constant attention, both by academics and practitioners, because it is necessary to take into account the impact of a large number of factors in management decisions. Factors can be both external to the organization and internal. These factors include: changes in the legislative framework for the management of economic facilities, changes in the working conditions of organizations caused by the emergence of new products in the foreign and domestic markets, etc. The issue of building effective governance structures based on a systemic approach continues to be a pressing issue. The article considers the essence of the organization as a object of management, and also defines that this concept is understood not only by enterprises, firms, but also by mesomacrostructures, namely the region, the power, individual industries. This is an emphasis on approaches to understanding the essence of the structure. The research and justification is based on a systematic management approach. Approaches to modeling the organization's management structure at the production level have been analyzed and evaluated. When building the organization's management structure, the main element of the system is the management task. Management tasks are formed in complexes, are based on the common problems that need to be solved in the relevant functional areas of the organization's activities. Structural units of the organization are formed on the basis of combining tasks into complexes (subsystems). These complexes are formed on the basis of the functional affiliation of the relevant conditions of the organization's units. The formation of tasks in complexes excludes duplication of the functions of management staff, which makes it possible to determine the rational number of necessary employees. On this basis, the method of building the structure of the organization's management system at the level of the state economy, individual industries, regions, which is the author's well-founded proposals, which can be used in practical activities by state institutions.

Key words: organization, management structure, modeling, system, macro level, methodology, methods. 